\title{
ANTI-INFLAMMATORY ACTIVITY OF PARTIALLY PURIFIED LECTIN FROM PRAECITRULLUS FISTULOSUS PHLOEM EXUDATES.
}

\author{
MADHU CS, SHARADA AC* \\ Department of Biochemistry, Yuvaraja’s College, University of Mysore, Mysuru, Karnataka, India. Email: sharadaac@gmail.com
} Received: 27 July 2018, Revised and Accepted: 29 August 2018

\begin{abstract}
Objective: The objective of the present study is to determine the anti-inflammatory effect of a partially purified lectin from phloem exudates against paw edema mice model.

Methods: Partially purified lectin was prepared by phloem exudates in phosphate buffer saline followed by ammonium sulfate precipitation and dialysis. Anti-inflammatory activity was determined against carrageenan-induced mice model and inhibition of nitric oxide (NO) production was determined.

Results: Partially purified lectin exhibited promising anti-inflammatory activity at $50 \mathrm{mg} / \mathrm{kg}$ b.w. by reducing the edema volume significantly up to $64 \%(* * \mathrm{p}<0.01)$ against control mice. Decrease in myeloperoxidase activity and N0 production in paw exudates was observed up to 55.90 ( $\mathrm{p}<0.05)$ and $47.22 \%(* \mathrm{p}<0.05)$, respectively, and this supports the anti-inflammatory property of the partially purified lectin.
\end{abstract}

Conclusion: This finding indicated that further studies needed to purify and characterize a novel lectin from Praecitrullus fistulosus for elucidating the molecular mechanism of anti-inflammatory activity.

Keywords: Inflammation, Lectin, Nitric oxide, Myeloperoxidase.

(C) 2019 The Authors. Published by Innovare Academic Sciences Pvt Ltd. This is an open access article under the CC BY license (http://creativecommons. org/licenses/by/4. 0/) DOI: http://dx.doi.org/10.22159/ajpcr.2019.v12i1.28670

\section{INTRODUCTION}

Inflammation is an evolutionary process in the body gain a great benefit for maintaining homeostasis. The inflammation may cause due to a microbial infection, cellular damage, stress and other chemicals irritants, etc. [1]. Among vertebrates, the inflammatory cascade is a complex process associated with immunological, physiological, and behavioral responses associated with cytokines and other immunological signaling molecules [2]. The cascade mainly involves an increase in microvessel permeability, migration of cell types, the growth of new tissues, and blood vessels [3]. During inflammation, a diverse group of molecules or substances called as pro-inflammatory mediators such as histamines, bradykinins, nitric oxide (NO), serotonin, and prostaglandins was released. These substances may significantly contribute to the classical picture of heat, redness, pain, selling, and diminished function associated with inflammation and may cause hyperalgesia or allodynia [4]. Acute inflammation refers to the initial response of the immune system against foreign bodies and tissue injury. It is a rapid time-limiting process, mediated by various substances such as eicosanoids and vasoactive amines which significantly stimulate the plasma movement and leukocytes into the inflammation site [5]. During tissue inflammation, increases in vasodilatation and recruitment of capillaries and increases in vascular permeability cause extravasations of plasma to lead to tissue edema. This causes migration of leukocytes, especially neutrophils [6]. Free radical species such as hydrogen peroxide $\left(\mathrm{H}_{2} \mathrm{O}_{2}\right)$, NO, molecular oxygen $\left(\mathrm{O}_{2}-\right)$, and superoxide radicals may significantly contribute to tissue inflammation. Especially, NO plays a key role in cell survival and cell death, cause pro-inflammatory effects on various immune and associated cells [7]. Increases in NO show the significant increases in macrophages in inflammatory sites.

It has been reported that currently available anti-inflammatory drugs which include NSAIDs (nonsteroid anti-inflammatory drugs) and opioids were not functioning in all cases, due to their low potency. These drugs cause side effects on gastrointestinal complications such as ulcers, perforating, vomiting or nausea, bleeding, constipation, and cognitive impairment [8]. As a result, the identification or development of novel alternatives has necessary and beneficial [9]. Previous studies taken up by various research groups showed that the effect of plantderived lectins can alter the immune system and thereby it blocks the inflammation cascade. Lectin from Caulerpa cupressoides possesses anti-inflammatory activity by inhibiting the leukocyte migration in a murine model of inflammation and lectin from Synadenium carinatum inhibits recruitment of immune cells to the lung in an asthma murine model by altering the expression of transcription factor necrosis factor (NF-kB) $[10,11]$. In the present report, we investigate the partially purified lectin; Praecitrullus fistulosus lectin-like protein (PfLP) which possesses anti-inflammatory activity against carrageenan-induced paw edema in mice model. We also evaluate the NO content in paw homogenate tissues. Decreases in NO content in treated group support the anti-inflammatory activity of PfLP. In future dietary, lectin may play a key role to develop a novel therapeutics against various diseases associated with inflammation.

\section{METHODS}

Materials

All the chemicals used in the present study were procured from SigmaAldrich and Hi-Media.

\section{Collection and authentication of plant material}

Samples were collected from local area farmers, Mysore, and authenticated by Dr. Sharvani K.A, Assistant professor, Department of Botany, Yuvaraja's College, University of Mysore, Mysuru. The herbarium (Accession number: YCM(UOM)0266) was prepared and deposited at the Department of Botany, Yuvaraja's College, University of Mysore. 


\section{Preparation of phloem exudates}

Phloem exudates were processed and prepared as described earlier and the partially purified lectin sample was prepared and named as PfLP [12]. Protein concentration was determined using the Bradford assay as described earlier [13].

\section{In vivo anti-inflammatory activity}

Animals

Male Swiss albino mice (27 \pm 2 g) were obtained from the Central animal facility, DOS in Zoology, University of Mysore, Mysuru. The animals were maintained as per the Institutional Animal Ethical Committee (IAEC- Ref No: UOM/IAEC/10/2017) guidelines. They are fed with standard diet and water ad libitum procured from Krishna enterprises, Bengaluru. All animals were acclimatized for 1 week with a constant temperature of $22 \pm 2^{\circ} \mathrm{C}$, with $12 \mathrm{~h}$ dark-light cycle, before the experimental sessions.

\section{Preparation of $1 \%$ of carrageenan}

Carrageenan was procured from Sigma-Aldrich. 1\% of carrageenan was prepared by dissolving $0.1 \mathrm{~g}$ of carrageenan in $10 \mathrm{ml}$ of $0.9 \% \mathrm{NaCl}$.

\section{Carrageenan-induced paw edema assay}

Anti-inflammatory activity of PfLP was evaluated by the acute inflammatory study as described earlier with slight modifications [14]. Acute inflammatory was induced using $1 \%$ of carrageenan $(100 \mu \mathrm{l} / \mathrm{paw})$ into the right hind paw of each mouse. The edema was induced by injecting into subplantar tissue of the right hind paw of each mouse. Group I receives saline acts as control, Groups II and III receive $25 \mathrm{mg} /$ $\mathrm{kg}$ and $50 \mathrm{mg} / \mathrm{kg}$ of $P f L P$, respectively, and Group IV receives diclofenac $(10 \mathrm{mg} / \mathrm{kg}$ ) were administered intraperitoneally, $1 \mathrm{hr}$ before the injection of carrageenan and paw volume was measured using Vernier caliper and leg weight was recorded at post scarification of the animals.

\section{Histopathology staining}

Histological changes of treated and untreated samples were examined as described earlier in section. Briefly, collected paw edema tissues from various groups were fixed using $4 \%$ paraformaldehyde and embedded in paraffin wax and $10 \mu \mathrm{m}$ sections were made using microtome (SLEE Cryostat). The sections were observed under low power (910) light microscope to identify the histological changes.

\section{MPO assay}

Myeloperoxidase (MPO) activity was determined to evaluate the neutrophils concentration in the inflammation tissue as described earlier with slight modifications [15]. Briefly, tissue from paw was homogenized using $1 \mathrm{ml}$ of buffer ( $5 \mathrm{~g} \mathrm{HTAB} / \mathrm{L}$ in $50 \mathrm{mM}$ potassium phosphate buffer, $\mathrm{pH}$ 6) using homogenized, and homogenized samples were subjected to centrifugation at $10,000 \mathrm{rpm}$ at $4^{\circ} \mathrm{C}$ for $10 \mathrm{~min}$ and supernatant was subjected to enzyme activity, as an index of migration of cells, using the method as described earlier [16]. Obtained $100 \mu$ of the supernatant was incubated with $2.9 \mathrm{ml}$ of phosphate buffer containing substrate $\left(0.167 \mathrm{~g} \mathrm{mg} / \mathrm{ml}\right.$ of 0 -dianisidine with $\left.0.0005 \% \mathrm{H}_{2} \mathrm{O}_{2}\right)$. The absorbance was read spectrophotometrically at A460 $\mathrm{nm}$ using visible light for 2 min. Enzyme activity per gram tissue was calculated as follows:

MPOactivity $\left(\frac{\text { Units }}{g m}\right)=\frac{(\Delta A 460) X(13.5)}{\text { pawtissueweight }(g)}$

Where, $\Delta \mathrm{A} 460$ was changing in absorbance at $460 \mathrm{~nm}$ from 30 to $90 \mathrm{~s}$ (2 min measurements), 13.5 is coefficient determined that 1 unit MPO activity was the amount of enzyme that would reduce $1 \mathrm{mM}$ peroxide/min.

\section{No production assay}

The nitrite level in carrageenan-treated control and treated mice was determined as described earlier [17]. Homogenize clear supernatant was used as an indicator of NO production using Griess reaction. Briefly, the $150 \mu$ l of supernatant were incubated with an equal volume of Griess reagent (1\% sulfanilamide prepared in $3 \mathrm{~N} \mathrm{HCl}$ and $0.1 \% \mathrm{~N}$-naphthyl ethylenediamine) for $10 \mathrm{~min}$ at room temperature, and absorbance was read at $540 \mathrm{~nm}$ using a microplate reader and nitrite concentration was determined by comparing with standard graph construct using sodium nitrite.

\section{Statistical data analysis}

Values are expressed as mean \pm standard error of the mean for control and experimental samples. Statistical analysis was performed by analysis of variance, followed by the Bonferroni's test and Student's t-test using GraphPad software prism 5.1.

\section{RESULTS}

\section{Effect of $P f L P$ on carrageenan-induced paw edema in mice}

The results of i.p administration of diclofenac $(10 \mathrm{mg} / \mathrm{kg})$ and PfLP (25 $\mathrm{mg} / \mathrm{kg}$ and $50 \mathrm{mg} / \mathrm{Kg}$ body weight) after 4-h induction on carrageenan-induced paw edema $\left(\mathrm{mm}^{3}\right)$ against control group were summarized in Fig 1c. Change in leg weight of each mouse in a group (standard deviation \pm mean value) also summarized in Fig $1 \mathrm{~d}$. On administration of PfLP shows a significant reduction in edema volume at all doses, i.e., $25 \mathrm{mg} / \mathrm{kg}$ shows $28.45 \pm 2.37 \%\left({ }^{*} \mathrm{p}<0.05\right)$ and $50 \mathrm{mg} / \mathrm{kg}$ shows $64.01 \pm 1.97 \%\left({ }^{* *} \mathrm{p}<0.01\right)$ of inhibition against a control group. The standard drug diclofenac shows a significant reduction in edema of $68.87 \pm 3.21 \%\left({ }^{* *} \mathrm{p}<0.01\right)$ at $10 \mathrm{mg} / \mathrm{kg}$ following of its administration against to the untreated control group.

Examination of paw tissue supports the anti-inflammatory activity of PfLP effectively inhibits neutrophils accumulation in the inflamed area. A large number of neutrophils were accumulated in inflammatory tissue area when compared with the diclofenac-treated and PfLP-treated mice groups as shown in Fig. 1a.

\section{Effect of PfLP on MPO activity in carrageenan-injected mice}

Results of i.p administration of PfLP on MPO activity (Abs at $450 \mathrm{~nm}$ ) were evaluated that in carrageenan-injected mice hind paw tissue lysate is shown in Fig 2a. PfLP gradually decreases the MPO activity in PfLP-treated animals at the two different does, i.e. $25 \mathrm{mg} / \mathrm{kg}(0.721$ OD-** $\mathrm{p}<0.01)$ and $50 \mathrm{mg} / \mathrm{kg}\left(0.411-0 D ;{ }^{* * *} \mathrm{p}<0.001\right)$ against a control group ( 0.925 OD), whereas diclofenac shows significant decreases in the MPO activity at $10 \mathrm{mg} / \mathrm{kg}\left(0.324-\mathrm{OD} ;{ }^{* *} \mathrm{p}<0.001\right)$.

\section{Effect of $P f L P$ on NOx levels in carrageenan-injected mice}

Effect of PfLP on NO production in treated and control group mice were determined by estimate the nitrite concentration $(\mu \mathrm{M})$ using Griess reagent was summarized in Fig $2 \mathrm{~b}$. On treatment in a dose-dependent study with PfLP-treated group mice shows significant decreases in nitrite level up to $27 \pm 1.03(\mu \mathrm{M})\left({ }^{*} \mathrm{p}<0.05\right)$ and $17.5 \pm 0.978(\mu \mathrm{M})$ $\left({ }^{* *} \mathrm{p}<0.001\right)$ at $25 \mathrm{mg} / \mathrm{kg}$ and $50 \mathrm{mg} / \mathrm{kg}$, respectively, compared to the untreated control mice of $36 \pm 2.01(\mu \mathrm{M})$. Significant reduction of nitrite concentration is directly proportional to the NOx concentration during inflammation site. Whereas, mice received standard drug diclofenac $(10 \mathrm{mg} / \mathrm{kg})$ show a drastic reduction in nitrite level up to $12 \pm 1.45(\mu \mathrm{M})$ $\left({ }^{* *} \mathrm{p}<0.001\right)$ level.

\section{DISCUSSION}

Inflammatory reactions, characterized by various cellular and vascular process, have an important role in the activation of lipoxygenase (LOX) and cyclooxygenase enzyme (COX) resulting in the release of inflammatory molecules such as prostaglandins and leukotrienes derivatives. During tissue damage/vascular inflammation, the number of events that taking place to cause inflammation such as migration of leukocytes, production of pro-inflammatory cytokines such as interleukins, NO, tumor necrosis factor- $\alpha$, NF-kB translocation, tissuespecific expression of LOX, and COX cascades leads to the production of prostaglandins and leukotrienes [18]. Developing novel non-toxic therapeutics are one of the challenges ahead in the field of inflammation 


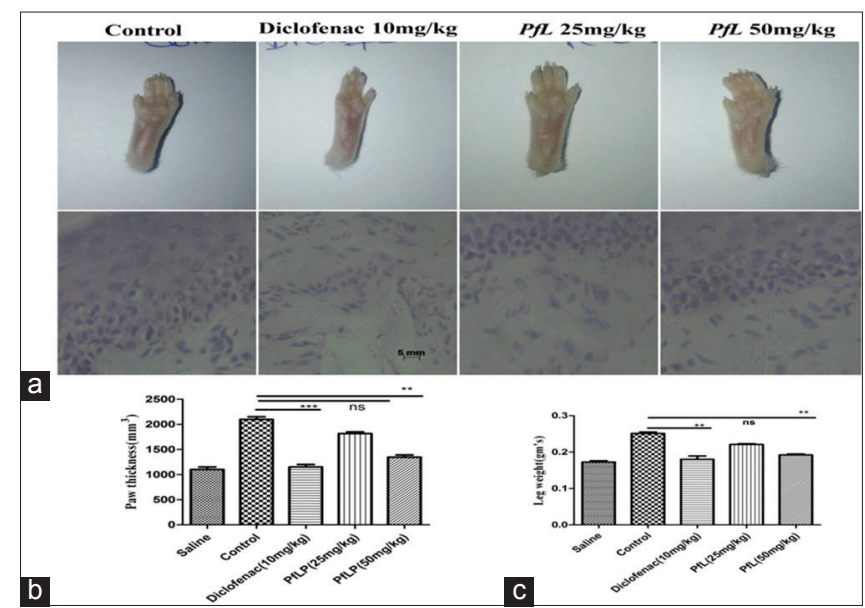

Fig 1. (a) Morphology of carrageenan induces mice paw and histopathology staining of control and treated groups, (b) Paw thickness $\left(\mathrm{mm}^{3}\right)$, (c) Leg weight. Data represent standard devaition \pm standard error of the mean (ns - no significant, $\left.{ }^{*} \mathrm{p}<0.05,{ }^{* *} \mathrm{p}<0.01\right), \mathrm{n}=3$

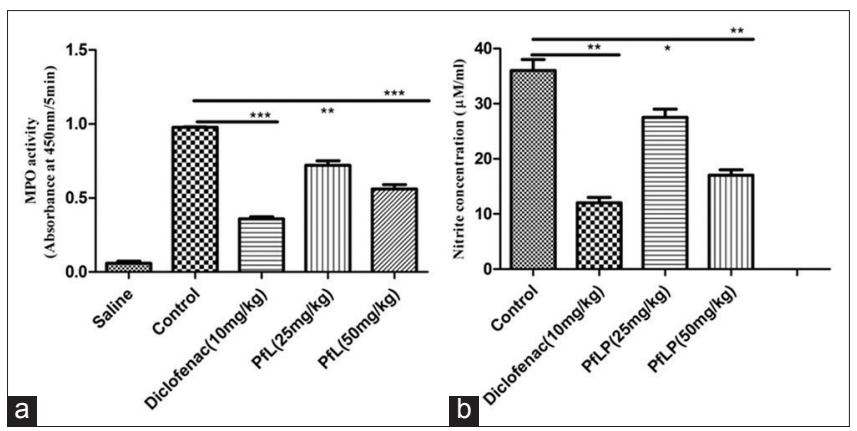

Fig. 2: (a) Myeloperoxidase activity assays (b) nitric oxide production assay. Data represent standard deviation \pm standard error of the mean (ns - No significant, ${ }^{*} \mathrm{p}<0.05,{ }^{* *} \mathrm{p}<0.01$, $\left.{ }^{* * *} \mathbf{p}<0.001\right) \mathrm{n}=3$.

biology. At present, available drugs exhibit secondary complication such as depletion of hematological cells, hepatotoxicity, and renal dysfunction. Several reports have shown the anti-inflammatory or acute inflammation inhibition studies using plant lectins in mice models. Recently, chitin-binding lectin from Canna limbata seeds and lectin from Bauhinia monandra possesses anti-inflammatory and antinociceptive activity in mice model $[19,20]$.

Our previous study exhibits promising lectin activity in phloem exudates of Praecitrullus fistulosus [21]. With the continuation of our work, we elucidate the role of lectin during inflammatory condition. On pre-treatment of $P f L P$ before the subplantar injection of carrageenan exhibits promising anti-inflammatory activity in a dose-dependent manner. The decrease in the paw volume and leg weight supports our findings. Previous studies showed that lectin from plants competitively binds the glycosylated selectin on the extracellular membrane of leukocytes and endothelial cells and thereby it reduces the rolling and adhesion of neutrophils on the endothelium region [22]. From the study suggested that the lectins inhibit the vascular inflammation mediated by adhesion of immune cells [23]. Extravasations of neutrophils or migration of neutrophils into the inflamed area lead to cause activation of tissue-specific hydrolytic enzymes [24]. Histopathology studies of both treated and control mice suggesting that a decrease in the accumulation of neutrophils in the inflamed region supports the antiinflammatory activity of PfLP. Increase in MPO activity is considered as a hallmark of cell infiltration (mainly neutrophils) in the inflamed tissue region. MPO enzyme abundantly found in neutrophils and it low amount in macrophages and monocytes [25]. Neutrophils concentration in the inflamed tissue area was measured by estimating the MPO activity. Histopathology studies and MPO estimation in tissue area support the anti-inflammatory activity of $P f L P$.

NO is a free radical produced in mammalian cells, plays an important role in cell survival and death, and exhibits a pro-inflammatory effect in various types of cells [7]. NO causes a detrimental effect on normal cells which may act as toxic. Harmful effects of NO depend on the NO concentration, combination, and formation of toxic derivatives, pathophysiological condition, and responses of target tissue/cell $[26,27]$. Therefore, inhibition of NO production during the inflammatory process may be the potential therapeutic implications. In this study, we evaluate the NO concentration in the hind paw tissue in both control and treated mice, as shown in Fig $2 \mathrm{~b}$. PfLP significantly inhibits the NO production in the carrageenan-injected mice at the dose of $50 \mathrm{mg} / \mathrm{kg}$ body weight compared to the control mice, in the late phase of the inflammation. This shows the anti-inflammatory effect of PfLP. From the above studies, we conclude that lectin may have the potential ability to inhibit or alter the inflammation responses by involved in the various pathways.

\section{CONCLUSION}

This work summarizes the anti-inflammatory activity of a PfLP from Praecitrullus fistulosus that is predominantly attributable inhibition of acute inflammation in a paw edema model. The study also suggested that PfLP may involve the inhibition of NO production by altering the NOS enzyme activity, thereby it reduces the inflammatory associated pain. However, it has been suggested that further molecular mechanism needs to explore the involvement of $P f L P$ in reducing inflammation, and it may consider as a promising candidate in the development of new therapeutics against inflammation-associated diseases.

\section{ACKNOWLEDGMENT}

The authors would like to acknowledge the Teresian Research Foundation and Dr. H.N Yajurvedi, DOS in Zoology, University of Mysore, Mysuru-11.

\section{FUNDING SOURCES}

This research did not receive any specific grant from funding agencies in the public, commercial, or not-for-profit sectors.

\section{AUTHORS' CONTRIBUTION}

Sharada AC designed the study and Madhu CS performed the experimental work.

\section{CONFLICTS OF INTEREST}

The authors declare that there are no conflicts of interest.

\section{REFERENCES}

1. Raj C, Ruslan M. Stress, inflammation, and defense of homeostasis. Mol Cell 2014;54:281-8.

2. Ashley NT, Weil ZM, Nelson RJ. Inflammation: Mechanism, costs, and natural variation. Ann Rev Ecol Evol Syst 2012;43:385-06.

3. Geert WS. Analysis of inflammation. Annu Rev Biomed Eng 2006;8:93-151.

4. Howard K, David R, Wei H, Tong Z, Guangfa W, Min H, et al. Measurement of inflammation and oxidative stress following drastic changes in air pollution during the Beijing olympics: A panel study approach. Ann N Y Acad Sci 2010;1203:160-7.

5. Charles NS, Nan C, Thomas E, Van D. Resolving inflammation: Dual anti-inflammatory and pro-resolution lipid mediators. Nat Rev Immunol 2008;8:349-61

6. Carlsson O, Rippe B. Peritoneal lymphatic absorption, and solute during zymosan-induced peritonitis in the rat. Am J Physiol 1999;277:1107-12. 
7. Garcia X, Stein F. Nitric oxide. Semin Pediatr Infect Dis 2006;17:55-7.

8. Labianca R, Sarzi-Puttini P, Zuccaro SM, Cherubino P, Vellucci R, Fornasari D. Adverse effects associated with non-opioid and opioid treatment in patients with chronic pain. Clin Drug Investig 2012;1:53-63.

9. Jaishree V, Badamia S, Kumar MR, Tamizhmani T. Antinociceptive activity of swertiamarin isolated from Enicostemma axillare. Phytomed 2009; 16:227-32.

10. Vanderlei ES, Patoilo KK, Lima NA, Lima AP, Rodrigues JA, Silva LM, et al. Antinociceptive and anti-inflammatory activities of lectin from the marine green alga Caulerpa cupressoides. Int Immunopharmacol 2010;10:1113-8.

11. Rogerio AP, Cardoso CR, Fontanari C, Souza MA, Afonso-Cardoso SR, Silva EV, et al. Anti-asthmatic potential of a D-galactose-binding lectin from Synadenium carinatum latex. Glycobiology 2007;17:795-804.

12. Madhu CS, Balaji KS, Shankar J, Sharada AC. Anticancer and antiangiogenic effect of partially purified lectin from Praecitrullus fistulosus fruit on the in-vitro and in vivo model. Biomed Pharmacother 2017;96:1299-309.

13. Bradford MM. A rapid and sensitive method for the quantification of a microgram of protein utilizing the principle of protein-dye binding. Anal Biochem 1976;7:248-54

14. Morris CJ. Carrageenan-induced paw edema in the rat and mouse. In: Winyard PG, Willoughby DA, editors. Inflammation Protocols. Methods in Molecular Biology. vol. 225. Totowa, New Jersey: Humana Press; 2003.

15. Lingaraju MC, Anand S, Begum J, Balaganur V, Kumari RR, Bhar RA, et al. Anti-inflammatory effect of di kaempferol rhamnopyranoside, a di flavonoid from Eugenia jambolana Lam leaves. Indian J Exp Biol 2015;54:801-07.

16. Koike K, Moore FA, Moore EE, Poggetti RS, Tuder RM. Endotoxin after gut ischemia-reperfusion causes irreversible lung injury. J Surg Res 1992;52:656-62.

17. Shastry KV, Moudgal RP, Mohan J, Tyagi JS, Rao GS. Spectrophotometric determination of serum nitrite and nitrate by copper-cadmium alloy. Anal Biochem 2002;306:79-82

18. Naomi O, Toshirou K. Molecular aspects in inflammatory events of the temporomandibular joint. Micro assay identification of mediators. Jpn Dent Sci Rev 2015;51:10-24.

19. Araujo LC, Aguiar JS, Napoleao TH, Mota FV, Barros AL, Moura MC, et al. Evaluation of cytotoxic and anti-inflammatory activities of extracts and lectins from Moringa oleifera Seeds. PLoS One 2013;8:e81973.

20. Campos JK, Araujo CS, Araujo TF, Santos AF, Teixeira JA, Lima VL, et al. Anti-inflammatory activity and antinociceptive activity of Bauhinia monandra leaf lectin. Biochim Open 2016;2:62-8.

21. Madhu CS, Sharada AC. Evaluation of haemagglutination and anticancer activity from Indian dietary plants. Int J Pharm Pharm Sci 2018; 10:105-08

22. Assreuy AM, Shibuya MD, Martins GJ, de Souza ML, Cavada BS, Moreira RA, et al. Anti-inflammatory effect of glucose-mannose binding lectins isolated from Brazilian beans. Mediators Inflamm 1997;6:201-10

23. Rocha BA, Delatorre P, Oliveira TM, Benevides RG, Pires AF, Sousa AS, et al. Structural basis for both pro and anti-inflammatory response induced by mannose-specific legume lectin from Cymbosema roseum. Biochimie 2011;93:806-16.

24. Sussan N, Ronen A. Leukocyte migration into inflamed tissues. Immunity 2014:41:694-07.

25. Bjornsdottir H, Welin A, Michaëlsson E, Osla V, Berg S, Christenson K, et al. Neutrophil NET formation is regulated from the inside by myeloperoxidase-processed reactive oxygen species. Free Radic Biol Med 2015;89:1024-35

26. Menaka KB, Ramesh A, Biju T, Suchetha KN. Estimation of nitric oxide as an inflammatory marker in periodontitis. J Indian Soc Periodontol 2009; $13: 75-8$

27. Pramod SN, Vigneshwaran V, Venkatesh YP. Immunomodulatory effects of hemagglutinating lectins from potato (Solanum tuberosum) and Garlic (Allium sativum) on human and murine lymphocytes. Int $\mathbf{J}$ Pharm Pharm Sci 2015;7:147-53. 